\title{
Characterization of Electrodes Membrane PVA- Enzyme Coating PVC-KTPCLPBas Urea Sensors With SEM-EDX, XRDand UV-Vis
}

\author{
Abd Hakim $\mathrm{S}^{1}$., Krista Tarigan ${ }^{2}$, Manihar Situmorang ${ }^{3}$,Timbangen Sembiring ${ }^{4}$, and Fatima \\ Sari Ritonga ${ }^{5}$ \\ \{abdhakims@unimed.ac.id ${ }^{1}$, fatimasariritonga@unimed.ac.id², fmipa@usu.ac.id ${ }^{3}$, \\ msitumorang@unimed.ac.id $\left.{ }^{4}\right\}$ \\ Physics Department,Faculty of Math and Science, Williem Iskandar, Medan, Indonesia ${ }^{\text {, }}$ \\ Physics Department,Faculty of Math and Science, Bioteknologi, Medan, Indonesia ${ }^{2}$ \\ Chemistry Department, Faculty of Math and Science, Williem Iskandar, Medan, Indonesia $a^{3,4}$
}

\begin{abstract}
Potentiometric characteristics are significantly dependent on the composition of the membrane and the properties of the plasticizer. Characterization of membrane electrodes was carried out using (UV-Vis to see absorbance, SEM-EDX to see the morphology and atomic ratio and XRD to see the intensity ratio of u.a). Characterization of PVA membranes: PVC in the composition of $1: 1$ ie $0.0350 \mathrm{~g}$ PVA and $0.0350 \mathrm{~g} \mathrm{PVC}$, plasticizer $0.0100 \mathrm{~g} \mathrm{KTpClPB}$ with variation of enzyme coating on PVA on $1 \mathrm{x}, 2 \mathrm{x}$ and $3 \mathrm{x}$ electrode membranes, followed by each coting $1 \mathrm{x} 0.0350 \mathrm{~g}$ PVC $0.0100 \mathrm{~g} \mathrm{KTpClPB}$. The electrode membrane selected was PVA E 1X PVC -KTpCIPB $0.0100 \mathrm{~g}$ electrode membrane obtained optimum (absorbance, atomic ratio and intensity of u.a).
\end{abstract}

Keywords: ISE, membranePVA-enzyme coating PVCKTpCIPB,Characterization of membrane (UV-Vis, SEM-edx, and XRD).

\section{Introduction}

Potentiometric sensors are devices that measure the voltage between two indicator electrodes and the reference electrode depending on the concentration of the analyte, without contradicting the electrochemical cell (Wang in. Al, 2008). Analites bind the bioreceptor to the surface of the indicator electrode in a buffer solution, resulting in a potential difference between the two electrodes. Measurement of urea concentration in the blood shows kidney indications and liver function, liver / heart failure, protein input or excessive protein catabolism, malnutrition, pregnancy, shock and pressure. Biological bonding reactions were chosen for urease enzymes with PVA and PVC substrates, their interaction in the form of molecular adsorption to increase detection limits and selectivity of biosensors (Dey and Goswami, 2013). PVA is soluble in water and the enzyme urease dissolves in water, while $\mathrm{PVC}$ is not soluble in water. PVA and PVC are polymer matrices that have a $\mathrm{C}$ branch as a 
functional group. Conductive polymers are the basis of electrochemical sensors and biosensors, useful in improving public and environmental health due to rapid detection, high sensitivity, small size, and affordable for environmental monitoring and clinical diagnostics (Rahman et. Al, 2008) Potentiometric sensors provide attraction and can be achieved for biomedical, environmental and industrial analysis, these sensors are generally easy to use, portable, simple, and inexpensive.

\section{Materials and method}

\subsection{Materials}

The material used in the study is a standard urea 56180 Sigma-Aldrich, the enzyme EC 3.5.1.5 (Urease) U4002, 50-100 ku ix types, tungsten diameter of $1.0 \mathrm{~mm} 26756299.99 \%$ Aldrich, PVA [-CH2CHOH-]n, PVC $(\mathrm{CH} 2 \mathrm{CHCl}) n, \quad \mathrm{KTpClPB}$ (potassium tetrakis 4chlorophenyl borate), Tetrahydrofuran $\mathrm{C}_{4} \mathrm{H}_{8} \mathrm{O}$, were from Sigma-Aldrich and the method used is the potentiometric method.

\subsection{Tools}

The equipment used is SEM-edx (Bruker-129 eV Zeiss), UV-Vis (Ray Leigh UV-1601), XRD-6100(Shimazu), tungsten indicator electrode (W) and other supporting tools.

\subsection{Methods}

The materials used are membrane composites ( $\mathrm{W}_{\mathrm{PVA}}$ : $\mathrm{W}_{\mathrm{PVC} \text {-plasticizer }}=1: 1$ ) (Niu et. Al, 2013) where the mass of PVA and PVC are the same, according to (Vlascici et. Al, 2006), PVC ratio: plasticizer $=1: 2$, researchers use PVC: KTpClPB with a ratio of 1: 2 . The composition of the membrane outside the provisions is $0.0350 \mathrm{~g}$ PVA and PVC while $\mathrm{KTpCIPB}$ is $0.0100 \mathrm{~g}$ as follows. Preparation of enzyme PVA solution comes from a mixture of PVA solution and enzyme solution. $0.0350 \mathrm{~g}$ of PVA dissolved in $10 \mathrm{~mL}$ of hot water to cold water, after that $1 \mathrm{mg}$ of urease enzyme was dissolved in $0.5 \mathrm{~mL}$ consisting of water and alcohol with a ratio of $50 \%$ water: $50 \%$ alcohol. Whereas PVC-KTpClPB solution comes from $0.0350 \mathrm{~g}$ of PVC and $0.0100 \mathrm{~g}$ of KTpCIPB dissolved $10 \mathrm{~mL}$ of THF in beaker glass. Thus the PVA enzyme solution and PVC-KTpCIPB solution have been used to form membranes and membrane electrodes. Membranes and electrode membranes were characterized using SEMedx and XRD, while PVA-enzyme-KTpCIPB membrane solutions were characterized by UVVis.

\section{Result and discussion}

\subsection{Membrane 0.0350 g PVA-E PVC 0.0100 $\mathrm{g}$}

First, characterization of membrane solution $0.0350 \mathrm{~g}$ PVA-E PVC $0.0100 \mathrm{~g}$ from enzyme variation of $1.0 \mathrm{mg} 1.5 \mathrm{mg}$ and $2.0 \mathrm{mg}$, the results can be seen in Figure 1. Only a slight 
increase in the height of the absorbance peak from UV-Vis analysis of membrane solution 0 , $0350 \mathrm{~g}$ PVA-E PVC $0.0100 \mathrm{~g}$ at enzyme variation of $1.0 \mathrm{mg}$ the height of the absorbance peak is $0.4920,1.5 \mathrm{mg}$ the height of the absorbance peak is 0.5241 and $2.0 \mathrm{mg}$ the height of the absorbance peak is 0.6074 having a wavelength located between 291-292 nm from 280 - 500 $\mathrm{nm}$, the maximum absorbance height obtained at the $2.0 \mathrm{mg}$ enzyme. For the manufacture of membranes and membrane electrodes, $1.0 \mathrm{mg}$ of enzyme was used in $0.0350 \mathrm{~g}$ of PVA. According to (Aziz et al, 2018) that the mixed samples showed the highest peak absorbance peak, the absorbance was analyzed by UV-Vis in the range of 180-1000 nm.

Both membranes were analyzed using SEM-EDX to see pores and atomic ratios at $15 \mathrm{kV}$ acceleration stress (Mignardi di al, 2013) results can be seen in Figure 4. The three membrane electrodes were analyzed using X-ray diffraction (XRD) at $40 \mathrm{kV}$ and a current of $30 \mathrm{~mA}$ scanned from a diffraction angle of $7^{\circ}$ to $70^{\circ}$ at a rate of 2 to $0.02^{\circ} 2 \theta$ is used to determine the intensity of the mineral composition of the membrane electrode. Electrode membranes are made in three types, namely (1) the electrode is dipped once at a time of $0.0350 \mathrm{~g}$ of PVA enzyme after that wait 30 minutes for coting PVC-KTpCIPB is notated el.1 PVA E PVCKTpCIPB $0.0100 \mathrm{~g}$, (2) electrode immersion in $0.0350 \mathrm{~g}$ PVA enzyme solution after 30 minutes dipped again in the same solution for the second time, wait 30 minutes for coting PVC-KTpClPB notated el.2 PVA E PVC-KTpCIPB $0.0100 \mathrm{~g}$, (3) electrode immersion in $0.0350 \mathrm{~g}$ PVA enzyme solution after 30 minutes dipped again in the same solution for the second time and continue for the third, wait 30 minutes for coting PVC-KTpCIPB notated el.3 PVA E PVC-KTpCIPB 0, $0100 \mathrm{~g}$.

In Figure 2 SEM uses an acceleration voltage of $15 \mathrm{kV}$ for PVA-E 1x PVC $0.0100 \mathrm{~g}$ analyzing the membrane of (a) SEM obtained by many pores, (b) EDX obtained elements C, $\mathrm{O}, \mathrm{Cl}, \mathrm{K}, \mathrm{Si}, \mathrm{Ca}, \mathrm{Na}$ and $\mathrm{Mg}$ on the surface of PVA E1-PVC PVA-E membrane $0.0100 \mathrm{~g}$ with carbon $\mathrm{C}$ ratio is 11.11 , oxygen $\mathrm{O}$ is 1.85 , chlorine $\mathrm{Cl}$ is 0.18 , potassium $\mathrm{K}$ is 0.07 , silicon $\mathrm{Si}$ is 0.05 , calcium $\mathrm{Ca}$ is 0.05 , sodium $\mathrm{Na}$ is 0.05 , and magnesium $\mathrm{Mg}$ is 0.05 can be seen in table 1 . There are differences in images 2 and 3 of the element elements of the membrane composition $0.0350 \mathrm{~g}$ PVA-E 1x PVC $0.0100 \mathrm{~g}$ and PVA-E 2x PVC $0.0100 \mathrm{~g}$ less pores in Figure 3, and PVA-E elements $2 \mathrm{x}$ PVC $0.0100 \mathrm{~g}$ from EDX with a carbon $\mathrm{C}$ ratio of 10.40 , oxygen $\mathrm{O}$ is 2 , 54 , chlorine $\mathrm{Cl}$ is 0.22 , silicon $\mathrm{Si}$ is 0.09 , calcium $\mathrm{Ca}$ is 0.09 , potassium $\mathrm{K}$ is 0.07 , magnesium $\mathrm{Mg}$ is 0.04 .

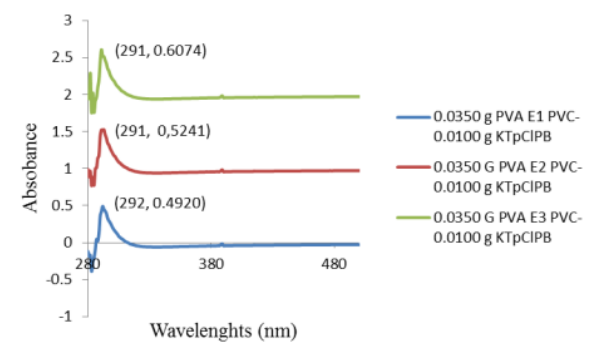

Fig. 1. PVA-E PVC membrane solution of UV-Vis in composition (a) $0.0350 \mathrm{~g}$ PVA-E1 PVC-0.0100 g, (b) $0.0350 \mathrm{~g}$ PVA-E2 PVC-0.0100 g, (c) $0.0350 \mathrm{~g}$ PVA-E3 PVC $-0.0100 \mathrm{~g}$. 
Based on table 1 membrane composition $0.0350 \mathrm{~g}$ PVA-E $1 \mathrm{x} 0.0100 \mathrm{~g}$ and table 2 composition of PVA-E 2x PVC $0.0100 \mathrm{~g}$ membrane shows that the carbon $\mathrm{C}$ ratio of $1 \mathrm{x}$ immersion is 11.11 and $2 \mathrm{x}$ dyeing is 10,40 , this is in accordance with the nature of PVA and $\mathrm{PVC}$ for a polymer matrix which has a $\mathrm{C}$ branch as a functional group.
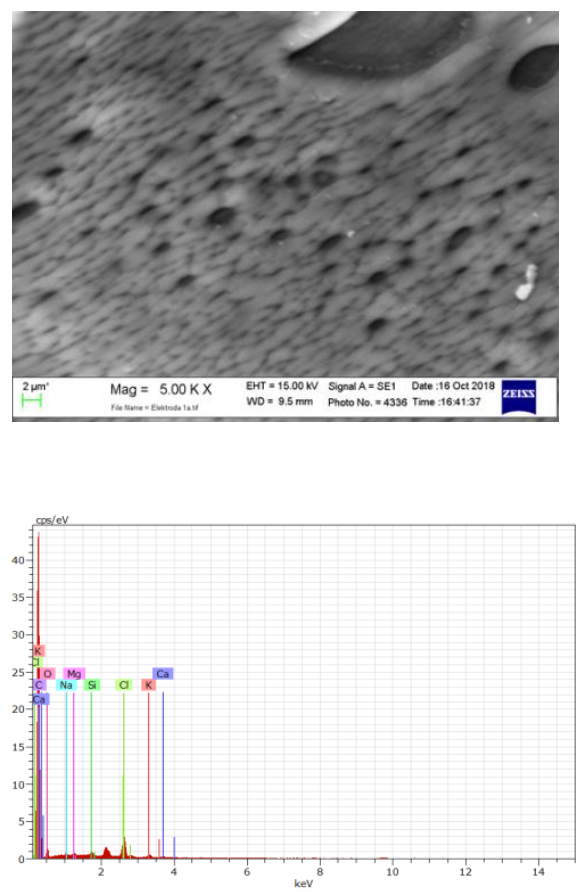

Fig. 2. PVA-E 1X PVC 0.0100 g membrane from (a) SEM, (b) EDX

Table 1. The ratio element of PVA-E 1 x PVC $0.0100 \mathrm{~g}$ membrane using SEM-EDX

\begin{tabular}{cccc}
\hline Element & Weight $\%$ & Atomic $\%$ & Ratio Atomic \\
\hline $\mathrm{C}$ & 86.91 & 91.93 & 11.11 \\
$\mathrm{O}$ & 7.57 & 6.01 & 1.85 \\
$\mathrm{Cl}$ & 3.78 & 1.35 & 0.18 \\
$\mathrm{~K}$ & 0.66 & 0.21 & 0.07 \\
$\mathrm{Si}$ & 0.39 & 0.18 & 0.05 \\
$\mathrm{Ca}$ & 0.26 & 0.08 & 0.05 \\
$\mathrm{Na}$ & 0.23 & 0.13 & 0.05 \\
$\mathrm{Mg}$ & 0.20 & 0.10 & 0.05 \\
\hline
\end{tabular}



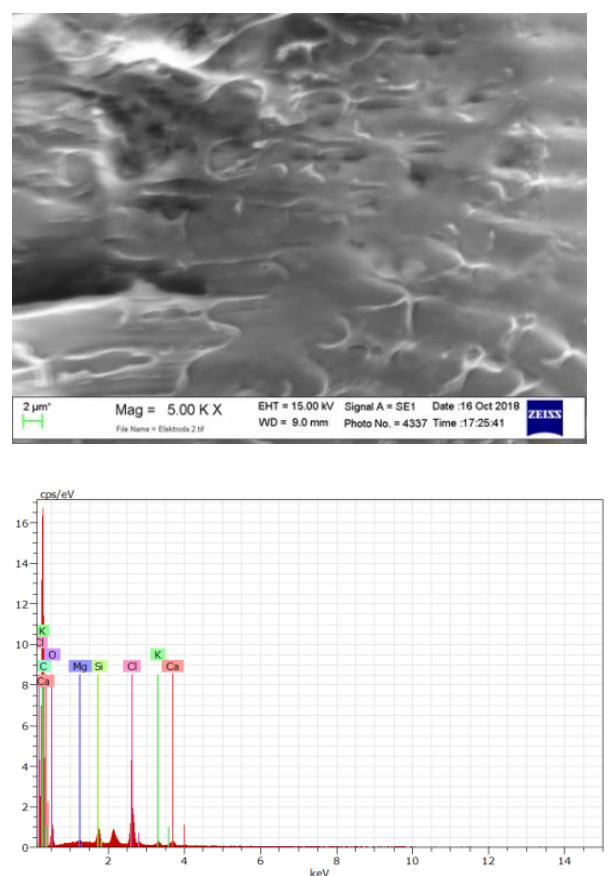

Fig 3. PVA-E $2 x$ PVC 0.0100 g membrane from (a) SEM, (b) EDX

Table 2. The ratio element of PVA-E 2x PVC $0.0100 \mathrm{~g}$ membrane using SEM-EDX

\begin{tabular}{cccc}
\hline Element & Weight $\%$ & Atomic $\%$ & Ratio Atomic \\
\hline $\mathrm{C}$ & 79.57 & 86.84 & 10.40 \\
$\mathrm{O}$ & 12.35 & 10.12 & 2.54 \\
$\mathrm{Cl}$ & 5.10 & 1.89 & 0.22 \\
$\mathrm{Si}$ & 1.14 & 0.53 & 0.09 \\
$\mathrm{Ca}$ & 1.09 & 0.36 & 0.09 \\
$\mathrm{~K}$ & 0.66 & 0.22 & 0.07 \\
$\mathrm{Mg}$ & 0.09 & 0.05 & 0.04 \\
\hline
\end{tabular}

Table 3. Ratio of element $\mathrm{C}$ from variations of PVA enzyme layers coating with PVCKTpCIPB only 1 time using SEM-EDX

\begin{tabular}{clc}
\hline Element & \multicolumn{1}{c}{ Membran } & Ratio Atomic \\
\hline & PVA E 1 layer PVC- & 11.11 \\
$\mathrm{C}$ & KTpCIPB 0.0100 g & \\
& PVA E 2 layer PVC- & 10.40 \\
& KTpClPB 0.0100 g & \\
\hline
\end{tabular}




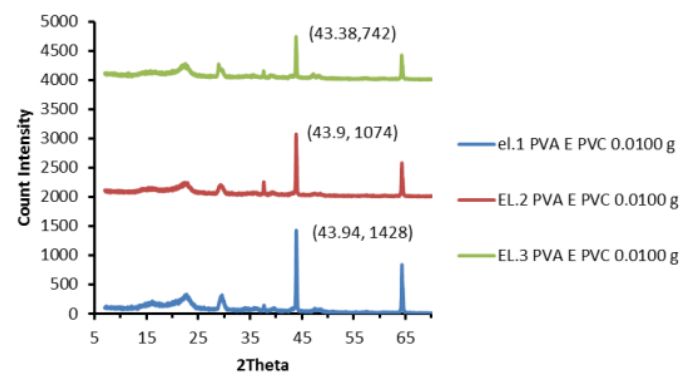

Fig. 4. PVA-E PVC-KTpCIPB membrane layer of XRD on indicator electrode (a) el.1 one layer, (b) el.2 two layer, (c) el.3 three layer

Table 4. Count Intensity $\mathrm{C}$ of the variation layer of $\mathrm{KTpCIPB}$ on the electrode with PVA enzyme still using XRD

\begin{tabular}{lcc}
\hline Membran Elektroda & 2Theta (deg) & $\begin{array}{c}\text { Count } \\
\text { Intensity }\end{array}$ \\
\hline PVA E 1X PVC- & 43.92 & 1428 \\
KTpClPB 0.0100 g & 43.9 & 1074 \\
PVA E2X PVC- & & \\
KTpCIPB 0.0100 g & 43.88 & 742 \\
PVA E3X PVC- & & \\
KTpClPB 0.0100 g & & \\
\hline
\end{tabular}

Based on table 3 and table 4 there is a comparable effect between ratio carbon $\mathrm{C}$ and XRD diffraction intensity, ie PVA E 1 layer PVC-KTpCIPB $0.0100 \mathrm{~g}$ and PVA E 2 layer PVCKTpCIPB $0.0100 \mathrm{~g}$. According to Figure 4 the optimum amount of diffraction intensity was obtained in PVA E 1X PVC-KTpCIPB $0.0100 \mathrm{~g}$ and there is a change in the height of the absorbance peak through the UV-Vis characterization in Figure 1, followed by a change in the height of the peak diffraction intensity with a diffraction angle of about 43 degree can be seen in Figure 4.

\section{Conclusion}

Characterization of PVA-enzyme PVC-KTpClPB membrane solution analyzed by UVVis and PVA- Enzyme PVC-KTpCIPB membrane electrodes were analyzed by SEM-EDX to determine the ratio carbon $\mathrm{C}$ and $\mathrm{XRD}$ ratios to determine the intensity of the diffraction degree, as follows:

1. Characterization of PVA-enzyme and PVC-KTpCIPB solutions for UV-Vis were analyzed in the range 280-500 nm obtained the highest peak absorbance at wavelengths 291 and 292 nm.

2. Characterization of PVA-enzyme PVC- KTpCIPB membrane electrodes with SEM-EDX and XRD obtained the best at $0.0350 \mathrm{~g}$ PVA $1 \mathrm{mg}$ enzyme one layer and one coating PVC$0.0100 \mathrm{~g} \mathrm{KTpCIPB}$. 


\section{Acknowledgements}

Thank you to Faculty of Mathematics and Natural Sciences of Universitas Negeri Medan for holding international conferences in the development of science, education and technology.

\section{References}

[1] Wang Y, Xu H, Zhang J and Li G.: Electrochemical Sensor for Clinic Analisis, Review, 8, 2043-2081 (2008)

[2] Dey, D., and Goswami T.:. Thin film Based Bio-electronic Sensors: Future Generation of Electronic Sensor Technology, Journal of current research in science JCRSDJ Vol. 1, No. 4, pp:199$204(2013)$

[3] Rahman M A, Kumar P, Park D S and Shim Y B.:. Electrochemical Sensors Based on Organic Conjugated Polymers, Review, Sensors, 8, 118-141 (2008)

[4]Niu H Y, Lang W Z, Liu Y X and Guo Y J.: Pervaporation Separation of Dimethyl Carbonate/Methanol Binary Mixtures with Poly(vinyl alcohol)-perfluorslulfonic Acid/poly(acrylonitrile) Hollow Fiber Composite Membranes. Fibers and Polymers 2013, Vol.14, No.10, 1587-1594 (2013)

[5] lascici D, Cosma E F and Spiridon O B.:. A New Composition for Co(II)-porphyrin-based Membranes Used in Thiocyanate-selective Electrodes, Sensors, 6, 892-900 (2006)

[6] Aziz S B, Faraj M G and Abdullah O G... Impedance Spectroscopy as a Novel Approach to Probe the Phase Transition and Microstructures Existing in CS:PEO Based Blend Electrolytes, Scientific reports 8:14308 (2018)

[7] Mignardi S, Corami A and Ferrini V.:. Immobilization of Co and Ni in Mining-Impacted Soils Using Phosphate Amendments, Water Air Soil Pollut 224:1447 (2013) 